\title{
Migration som trussel mod sammenhængskraft
}

Af Frede Vestergaard

Sikkerheds- og stabilitetspolitik er mere end militær sikkerhed, som det rettelig fremgår af Taksøe-Jensen-rapporten og regeringens udenrigs- og sikkerhedspolitiske strategi med henvisning til den massive befolkningstilvækst i Mellemøsten og Nordafrika. Migration som sikkerhedspolitisk udfordring for EU er undervurderet, fordi fokus rettes mod flygtninge og migranters vilkår og ignorerer de langsigtede konsekvenser for sammenhængskraften i modtagerlandene.

'Migration, ustabilitet og terrorisme' er et af de fem hovedemner/trusler i regeringens udenrigs- og sikkerhedspolitiske strategi for 2017-18; den første, der nogensinde er eksplicit formuleret. Regeringen vil arbejde for at mindske migrationsog flygtningepresset samt terrortruslen mod Europa og Danmark.

Danmark skal ifølge strategien 'forebygge nye flygtninge- og migrationsstrømme ved at skabe fred, sikkerhed og bedre fremtidsudsigter for mennesker dér, hvor de hører hjemme. Det kræver en styrket nærområdeindsats for at fremme stabilitet, vækst og udvikling i Mellemøsten og Afrika samt en bedre sikring af Europas grænser, lyder det.

Målet afspejler analysen af Danmarks udenrigspolitiske udfordringer i Taksøe-Jensen-rapporten Dansk diplomati og forsvar i en brydningstid. Vejen frem for Danmarks interesser og vordier mod 2030. Den er ikke snævert fokuseret på det militære, i modsætning til den forrige store sikkerhedspolitiske analyse, Hans Henrik Bruun-rapporten De sikkerhedspolitiske vilkår for dansk forsvarspolitik fra 2003, hvor ordene migration og illegale indvandrere kun akkurat bliver nævnt i forbifarten.

Men i dag dominerer flygtninge- og migrationsspørgsmålet den danske og europæiske debat som aldrig før. Omkring 1,3 mio. søgte asyl i Europa i 2015, og andre 1,2 mio. i 2016 ifølge Eurostat, mens tallet i 2017 ser ud til at være halveret til ca. 600.000 .

Faldet skyldes, at vestbalkanruten er lukket af landene langs ruten, og at EU på grund af stærk folkelig modvilje mod den

Frede Vestergaard er journalist med tilknytning til Weekendavisen. Han er uddannet cand.polit. og skriver blandt andet om de samfundsmæssige konsekvenser af den økonomiske udvikling, ofte med særlig interesse for bl.a. energi og miljø. 


\section{Den indre sikkerhed og stabilitet for Danmark og Europa handler om andet end potentiel terror. Den er et spørgsmål om migrationens omfang og dermed de økonomiske og sociale omkostninger ved at modtage et stort antal mennesker,}

ukontrollerede indvandring i 2015 i foråret 2016 indgik aftaler med Tyrkiet om, at EU bidrager kraftigt til at finansiere Tyrkiets udgifter til flygtningelejre for syriske flygtninge, mod at Tyrkiet ikke lader syriske og andre flygtninge rejse videre til Europa. Men middelhavsruten var fortsat åben. Siden har Italien i eftersommeren 2017 truffet aftaler med Libyens magthavere om at begrænse denne kanal.

Den folkelige modvilje mod den ukontrollerede indvandring til Europa i 2015 og 2016 har givet vind i sejlene til såkaldt populistiske partier, der tager afstand fra 'masseindvandringen'. Det er partier, som ofte forbinder EU med manglende løsninger på problemet. Det er der ifølge en holdningsundersøgelse fra amerikanske Pew Research Center fra september 2016, som omfatter 10 lande i Europa (dog ikke Danmark) stor klangbund for at gøre.

På den måde truer migrationen EU-samarbejdet med delvis opløsning. Indvandring spillede en afgørende rolle i juni 2016, da et flertal i UK - hvor Tony Blair i 1997 havde lempet reglerne for indvandring fra de tidligere kolonier - stemte ja til at forlade EU. I de fleste af de 'nye' EU-medlemslande i øst er der stor folkelig modvilje mod at blive dikteret at modtage flygtninge fra Mellemøsten som led i en EU-fordelingsordning, men det samme er tilfældet $i$ andre lande. I øvrigt ville sådanne tvangsplacerede flygtninge i de fattigste EU-lande formentlig efterfølgende søge mod mere velstående EU-lande som bl.a. Tyskland, hvorfra de ville have lettere ved at sende penge hjem til familien.

Der har i medierne været en tilbøje- lighed til at slå sig til tåls med, at de såkaldte populistiske partier ikke fik så stor fremgang - som medierne selv havde stillet i udsigt - ved valgene i 2017 i Frankrig, Tyskland, Holland, Østrig og Norge, men det skyldes bl.a., at de etablerede partier havde skærpet holdningen til indvandring. Og rent faktisk var tilslutningen ikke desto mindre stor til de indvandringskritiske partier.

I Italien, hvor der skal være valg i år, spiller spørgsmålet om kravene til italiensk statsborgerskab for migranter en stor rolle i valgkampen. I Sverige, hvor der skal være valg til september, har Socialdemokraterne og de fleste borgerlige partier reelt overtaget de indvandringskritiske Sverigedemokraters dagsorden, samtidig med at de holder sig for næsen, når de nærmer sig en sverigedemokrat.

\section{Økonomisk og social trussel}

Migrationen er ikke en militær trussel. Den kan potentielt lede til et antal religiøst inspirerede terrorhandlinger. Men selv de cirka 3.000 omkomne fra 9/11 er kun en lille brøkdel af eksempelvis antallet af trafikdræbte i USA hvert år.

Den indre sikkerhed og stabilitet for Danmark og Europa handler om andet end potentiel terror. Den er et spørgsmål om migrationens omfang og dermed de økonomiske og sociale omkostninger ved at modtage et stort antal mennesker, der ikke har forudsætninger for at klare sig på et arbejdsmarked, der i høj grad forudsætter et veluddannet personale. Og hvor lavt uddannet personale løser serviceopgaver såsom fx rengøring. De manuel- 


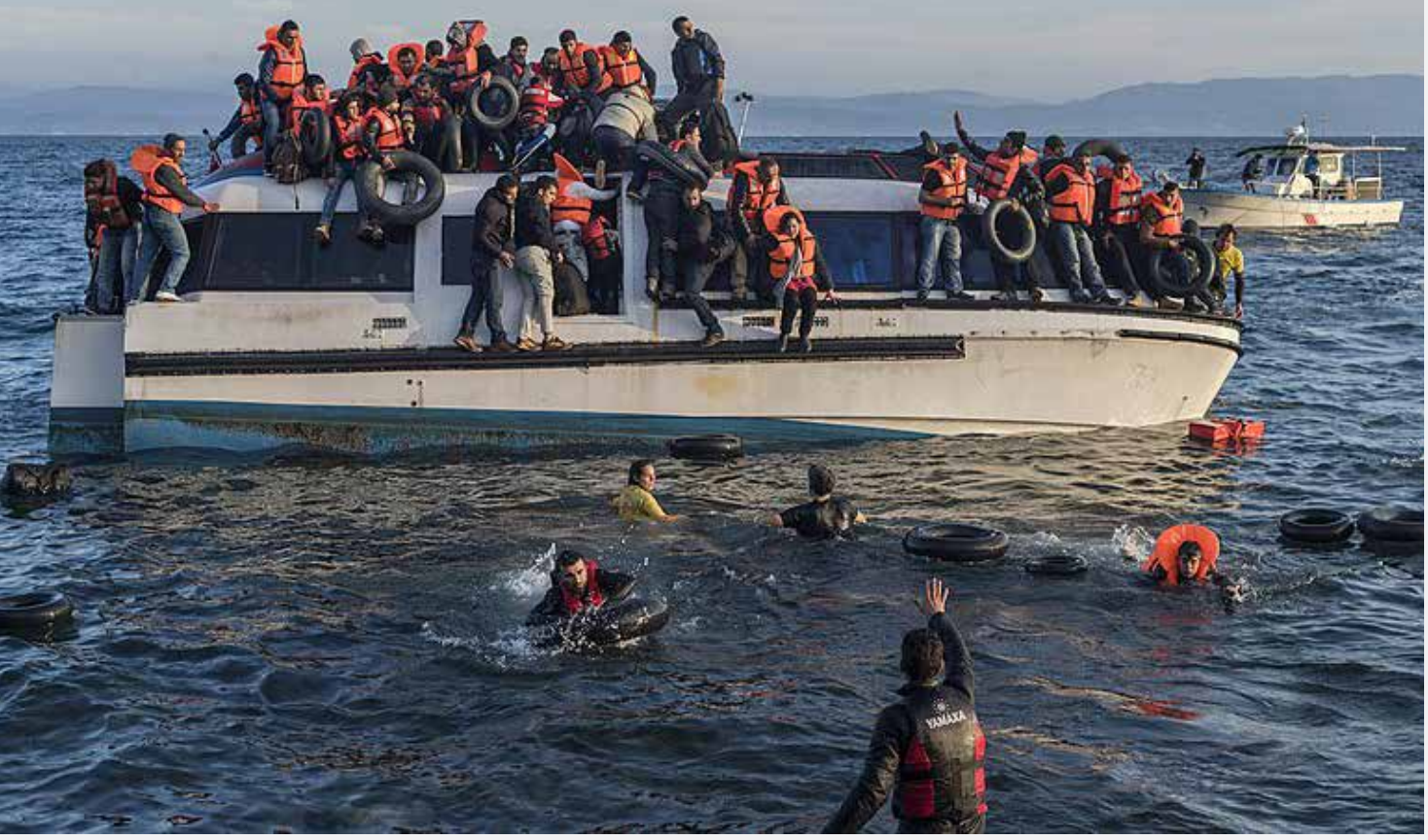

FOTO: Ggia via wikimedia commons

Syriske og irakiske flygtninge ankommer fra Tyrkiet til Lesbos, Grækenland, oktober 2015

le arbejdspladser i industrien er i vidt omfang udflyttet til lande med lavere løn eller er automatiseret og kræver højt kvalificeret personale.

At antallet også på kort sigt betyder noget, leverede Sverige et utvetydigt eksempel på i efteråret 2015. Mens den tyske forbundskansler Angela Merkel på sin pressekonference den 31 . august, som kommentar til det store antal asylsøgende, der søgte mod Tyskland, udtalte: "Vi har klaret så meget - vi klarer det" (Wir haben so vieles geschaftt - Wir schaffen dass), modtog Sverige så relativt mange flere end Tyskland, at statsminister Stefan Löfven den 24. november måtte meddele - med en grædende vicestatsminister Åsa Rom- son fra Miljøpartiet ved sin side - at Sverige strammede kraftigt op og gennemførte forskellige indgreb, der skulle få flygtninge til at søge asyl i andre EU-lande.

I Regeringskansliets pressemeddelelse fra den 24. november 2015 hed det: "Efter sommeren er antallet af flygtninge, som søger til Sverige, øget kraftigt, og bare i de sidste to måneder har 80.000 personer søgt asyl i Sverige. Af dem er der så mange børn og unge, at det modsvarer 100 nye skoleklasser hver uge. Myndigheder og kommuner har nu svært ved at klare opgaverne (...) Myndigheden for samfundsbeskyttelse og beredskab slår alarm $\mathrm{om}$, at vigtige samfundsfunktioner ikke kan klare opgaverne. Sverige kan ikke 
længere garantere tag over hovedet for dem, som søger til vort land, og den sidste uge har mennesker været tvunget til at sove udendørs. Derfor foreslår regeringen nu en række tiltag for at skabe et pusterum for svensk flygtningemodtagelse. Det kræver, at antallet af personer, som søger asyl og bevilges opholdstilladelse i Sverige, mindskes kraftigt. Regeringen vil derfor $i$ en periode tilpasse asylreglerne til EU's minimumsniveau for, at flere skal vælge at søge asyl i andre EU-lande".

Sverige indførte derfor ID-kontrol på færgen mellem Helsingør og Helsingborg samt på tog og busttrafikken over Øresundsbroen, men ikke på færgeruterne mellem Tyskland og Sverige, hvilket medførte, at også Danmark indførte grænsekontrol ved grænsen til Tyskland. Desuden ville asylsøgende fremover kun få midlertidig opholdstilladelse på tre år, der dog kunne forlænges, hvis flygtningen kunne opvise en skattepligtig indkomst på et niveau, som man kan leve af. Forud for kursskiftet var flygtninge fra Syrien siden 2013 på forhånd garanteret permanent opholdstilladelse, hvis de mødte op i Sverige. Indgrebet gjaldt også personer, der var ankommet før den 24 . november, men ikke havde fået deres sag behandlet.

Et anden vigtig ændring var, at en flygtning kun kunne få sin kernefamilie familiesammenført - ikke den udvidede familie - og at begge ægtefæller skulle være mindst 21 år. Der kom også krav om, at personen, der søger om familiesammenføring, skal kunne forsørge familiemedlemmer, der kommer til Sverige. Endelig blev det besluttet, at uledsagede børn un- der 18, som hidtil havde ret til at få familien til Sverige, hvis de fik asyl, fremover skulle aldersbestemmes medicinsk, hvis der var tvivl om alderen (i 2015 kom ca. 35.000 overvejende af hankøn).

Efterfølgende besluttede de regeringsbærende Socialdemokrater på deres kongres i oktober 2017, at Sverige bør bevare grænsekontrollen for øget sikkerhed, og fordi "sikkerhedssituationen i Europa er sådan, at vi behøver at have kontrol med vore grænser, ikke mindst på baggrund af terrorangrebet, som skete i Sverige den 7 . april", som det hed på partiets hjemmeside.

At så mange syriske flygtninge søgte til Sverige skyldtes i første række, at Sverige fra 2013 på forhånd havde garanteret permanent opholdstilladelse til asylsøgere, der nåede frem til Sverige. Men undersøgelserne viser også, at en hel del kom, fordi de i forvejen havde mere eller mindre fjern familie i Sverige som følge af Sveriges tre årtiers liberale praksis for tildeling af asyl til personer fra bl.a. Mellemøsten kombineret med generøse regler for efterfølgende familiesammenføring.

\section{Familiesammenføringer}

Også under fredelige omstændigheder spiller familiesammenføringsreglerne en stor rolle for visse grupper.

Ægteskab på tværs af grænser mellem personer fra højindkomstlande fører ikke til yderligere familiesammenføring via deres børn - $\mathrm{i}$ hvert fald ikke kun én vej - og parret slår sig ikke systematisk ned i det ene land frem for det andet.

Derimod har der hidtil været en meget

\footnotetext{
Ægteskab på tværs af grænser mellem personer fra højindkomstlande fører ikke til yderligere familiesammenføring via deres børn - i hvert fald ikke kun én vej - og parret slår sig ikke systematisk ned i det ene land frem for det andet.
} 
stærk tendens til, indvandrere/flygtninge, der allerede er kommet til et højindkomstland fra lavindkomstlande, hvor det er kulturel praksis, at familierne bestemmer eller har meget stor indflydelse på, hvem børnene skal gifte sig med, bruger et giftemodent barn som visum for en ægtefælle fra den udvidede familie i lavindkomstlandet til højindkomstlandet.

For Danmarks vedkommende er væksten $\mathrm{i}$ indvandrerbefolkningen med tyrkisk baggrund et klart eksempel på betydningen af familiesammenføringsregler. Da der blev lukket for arbejdskraftindvandring til Danmark fra ikke-EU-lande i 1973, var der knap 6.000 tyrkiske statsborgere i Danmark. De er siden ved familiesammenføringer, fødsler og andengenerationens henteægteskaber og børnebørn vokset til mindst 62.600 pr. 1. januar 2017 ifølge Danmarks Statistiks opgørelser. Til sammenligning er Tyrkiets folketal kun fordoblet i samme periode.

Denne praksis blev fra begyndelsen af nullerne $i$ et vist omfang begrænset som følge af bl.a. 24-årsreglen og tilknytningskravet, som senere er udhulet eller blokeret af domme fra Den Europæiske Menneskerettighedsdomstol. Betydningen af, at nye familier dannes ved henteægteskaber, er, at integrationen starter forfra, fordi det nye ægtepar typisk vil tale tyrkisk, arabisk, urdu osv. indbyrdes. Altså taler de ikke dansk i hjemmet eller ser dansk tv, men $\mathrm{fx}$ arabisk. Dette i modsætning til fx et dansk-brasiliansk ægtepar.

\section{Andengenerationsbørn}

Anden generation begynder derfor i skolen med svage danskkundskaber. Indvandrerbørn klarer sig gennemsnitligt dårligt i skolen, fremgår det af resultaterne fra folkeskolens afgangsprøver. Det er ikke et særligt dansk fænomen. Det forekom- mer også i andre lande i Europa. Det viser de såkaldte PISA-undersøgelser fra OECD. Diverse undersøgelser viser i øvrigt, at det hæmmer indlæringen også for majoritetseleverne, hvis antallet af indvandrer- eller andengenerationsbørn udgør et betydeligt mindretal i en skoleklasse. Det er en af migrationens sociale trusler: Indvandring skaber ulighed, og uligheden begynder i skolen. Stor ulighed er destabiliserende, i særlig grad når der opstår en synlig underklasse.

Dårlige resultater i grundskolen bremser muligheden for videre uddannelse, $\mathrm{i}$ særdeleshed for indvandrerdrengene, der klarer sig dårligst. Mange falder fra på uddannelser efter folkeskolen og bliver afhængige af diverse offentlige ydelser, fordi de mangler jobkvalifikationer. Og de unge kvinder bliver i vidt omfang hjemmegående efter at have fået børn, for sådan er det kulturelle mønster i familiens oprindelsesland.

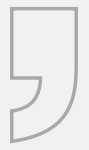

\section{Det er en af migrationens sociale trusler: Indvandring skaber ulighed, og uligheden begynder $\mathrm{i}$ skolen.}

Det er i øvrigt interessant, at i OECD's PISA-undersøgelse fra 2006 klarer immigrantelever sig lise så godt som majoritetsbefolkningen i tre traditionelle immigrantlande: Australien, Canada og New Zealand. Det fremgår ikke, hvad årsagen kan være, fx om det er et andet mix af indvandrere, eller om forklaringen er, at disse lande i mindre grad har karakter af velfærdsstater end mange europæiske lande. Hvis det sidste er tilfældet, er majoritetsbefolkningen i europæiske lande så villig til at acceptere, at velfærdssystemet (overførselsindkomsterne) af ikke-diskriminatoriske grunde forringes for alle for at få integrationen til at fungere? 
Lave beskæftigelsesfrekvenser for både mænd og i særdeleshed kvinder betyder, at ikke-vestlige indvandrere som gruppe betragtet gennemsnitligt modtager væsentligt større beløb fra eksempel dagpenge, kontanthjælp og førtidspension, end de selv betaler i skat. De ikke-vestlige efterkommere klarer sig bedre end forældregenerationen, men har som forældrene en lavere beskæftigelsesfrekvens end majoritetsbefolkningen.

\section{Økonomisk belastning}

Tilsammen begrænser det majoritetsbefolkningens muligheder for offentlig velfærd, som det har været tilfældet i en årrække. En undersøgelse fra Finansministeriet fra april 2017 angiver et tal på 16 mia. kr. for ikke-vestlige indvandrere og 17 mia. kr. for ikke-vestlige efterkommere, i alt 33 mia. kr. i nettobelastning af de offentlige finanser, svarende til halvanden pct. af BNP. Det samme ses i andre velfærdsstater i Vesteuropa. I Sverige var det godt to pct. af BNP før den seneste indvandringsbølge.

I lande som Storbritannien og de overs $\emptyset$ iske angelsaksiske lande er det anderledes. Der er den offentlige hjælp til personer i den arbejdsdygtige alder uden for arbejdsmarkedet begrænset i størrelse og varighed, og forskellen i beskæftigelsesfrekvens mellem indvandrere og majoritetsbefolkning er meget lille. Det er et forhold, der jævnligt afspejler sig i angelsaksiske analytikeres beskrivelse af den økonomiske betydning af indvandring, som de derfor anser for positiv.

Men i de europæiske velfærdsstater med relativt generøse overførselsindkomster og lønninger, som forudsætter en kvalificerende uddannelse, er det anderledes. Integrationen fungerer dårligt. Det lægger et pres på sammenhængskraften, at det er synligt, hvem der modtager, og hvem der betaler.
Desuden bidrager det til at øge uligheden i samfundet, at en overgennemsnitlig andel af de - med et canadisk begreb - synlige minoriteter i så udstrækning lever af offentlige ydelser eller af lavtlønnet servicearbejde som $\mathrm{fx}$ rengøring.

Sammenhængskraft er svært at definere; det handler bl.a. om kulturel identitet og kulturdissonans, social tillid og negative følelser over for ukontrolleret indvandring af flygtninge og økonomiske migranter hos store dele af den residerende befolkning, fordi de må afgive noget af det, som de og deres forfædre har skabt, eftersom der ikke må diskrimineres. Alternativet er at basere sociale ydelser og pensioner samt adgang til sundhedsydelser m.m. på optjenings- og forsikringsprincipper som i USA.

Det vil gøre det meget mindre attraktivt at søge til Danmark og Europa, men det ville også ramme 'vore egne' og dermed splitte sammenhængskraften. Det er ét af dilemmaerne.

\section{Momentum for fortsat migrationsvækst}

Familiesammenføringen og boligpolitikken - hvor indvandrere og flygtninge koncentrerer sig i store boligkomplekser, som oprindelig blev bygget til majoritetssamfundets lavindkomstfamilier - bidrager til at migrationen fremmer såkaldte parallelsamfund. Noget der forekommer i en række lande i Vesteuropa.

Familiesammenføringsreglerne skaber som nævnt i sig selv et momentum for fortsat vækst i indvandrerbefolkningen i Europa. Det samme gør den voldsomme befolkningsvækst i Europas sydlige og sydøstlige nærområder.

Taksøe-Jensen-rapporten nævner, at der på grund af befolkningssammensætningen med en høj andel unge er udsigt til en befolkningsvækst på 25 pct. i Mel- 
lemøsten og Nordafrika, mens der i Afrika i øvrigt er udsigt til en vækst på 40 pct. Med en sådan vækst er der ingen udsigt til, at migrationskrisen stopper af sig selv. Næppe heller ved at Danmark - sammen med andre lande - ved hjælp af udviklingsbistand m.m. søger at "forebygge nye flygtninge- og migrationsstrømme ved at skabe fred, sikkerhed og bedre fremtidsudsigter for mennesker dér, hvor de hører hjemme", som det hedder i regeringens udenrigs- og sikkerhedspolitiske strategi. Økonomiske migranter vil fortsat tro, at det bedste, de kan gøre for hurtigt at blive 'rige', er at komme til Europa og arbejde.

Og der vil utvivlsomt hen ad vejen også komme en række konflikter, der giver anledning til nye, store flygtningestrømme. Skal de stoppes, før de når ind over Europas grænser, vil der være brug for aftaler med Tyrkiet, Ægypten, Libyen og Maghreb-landene om at forhindre dem $\mathrm{i}$ at sætte både i vandet.

Et særligt problem er den illegale indvandring, som ofte opstår, når en asylsøger får afslag og alligevel forbliver i landet, eller når en person fra et ikke EU-land forbliver efter et visums eller opholdstilladelses gyldighedsperiode for at arbejde. Ifølge sagens natur er tallet svært at opgøre. Rockwoolfondens forskningsenhed har for Danmark benyttet sig af, hvor mange personer politiet er kommet i kontakt med ved diverse kontrolforanstaltninger på arbejdspladser, og når med forholdsvis stor usikkerhed frem til, at det i 2016 var 22.000 personer (med 95 pct. sandsynlighed mellem 19.000 og 25.000) mod 18.000 i 2015 og 12.000 i 2010. Den svenske, grønne og liberale hjemmeside migrationsinfo.se nævner, at man regner med mellem to og 8,8 millioner illegale indvandrere for hele EU.

En opstramning af den europæiske ind- vandringspolitik er dog ikke så ligetil.

Dels er der konventionerne og dertil Den Europæiske Menneskerettighedsdomstols dynamiske, udvidende fortolkning af Den Europæiske Menneskerettighedskonvention, som regeringen har erklæret at ville se kritisk på, mens Danmark i første halvår 2018 har formandskabet for Europarådet.

Dels er der hensynet til dem, der allerede er her. I Danmark er antallet af ikkevestlige indvandrere og deres efterkommere lige så stille vokset fra godt $50.000 \mathrm{i}$ 1980 til knap en halv million i 2016. Som med alle demografiske bevægelser er ændringen lille fra det ene år til det andet, men den akkumulerer.

Og dels er der i alle lande et stort mindretal, der afviser indvandringen som et problem og anser etnicitet og social og national/kulturel affinitet - som spiller en stor rolle for flertallet - for ligegyldige sociale konstruktioner af forestillede fællesskaber.

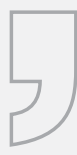

\section{Økonomiske migranter vil fortsat tro, at det bedste, de kan gøre for hurtigt at blive 'rige', er at komme til Europa og arbejde.}

Desuden er mediernes vinkling over for offentligheden af flygtninge- og indvandrerproblematikken som regel motiveret af et synd-for-dem-syndrom. Det samme gælder for migrationsforskeres og ngo' ers tilgang til migrationen, som snarere er, hvordan flere flygtninge og migranter kan hjælpes til Europa, end at tage bestik af, at et flertal - sommetider et stort flertal - af befolkningen i modtagerlandene er imod storstilet indvandring fra ikke-vestlige lande på grund af de langsigtede økonomiske, sociale og kulturelle konsekvenser og konfrontationer; fordi de ser migra- 
tionen $\mathrm{i}$ både de enkelte lande og mellem EU-landene indbyrdes som en trussel mod sammenhængskraften.

\section{Behov for indvandring til Europa?}

Men er der ikke behov for (flygtninge) indvandring til Europa på grund af de lave fødselstal i mange lande og befolkningens aldring. Umiddelbart kan det se sådan ud, men systematisk indvandring med det formål at skaffe arbejdskraft er kortsigtet generationsegoisme. Den er en umiddelbar hjælp, men udskyder bare problemet med mangel på arbejdskraft. Byrden ved befolkningens aldring bliver blot endnu større i fremtiden. Flygtningeindvandring må begrundes humanitært og ikke med mangel på arbejdskraft.

Denne problemstilling blev i begyndelsen af nullerne påvist af FN's befolkningsdivision i New York i en analyse med titlen Replacement Migration: Is it a solution to declining and aging populations?

FN's demografer satte sig for at analysere, hvad det ville betyde, hvis det lave fødselstal i mange europæiske lande - og visse andre lande i verden - med en fertilitetsrate under to, blev erstattet af indvandrere. De beregnede, hvad det vil betyde, hvis man for de daværende 15 EU-lande med 375,7 millioner indbyggere i 2000:

- Vil opretholde et uændret folketal fra 1995-2050, eller

- Vil opretholde en uændret arbejdsstyrke defineret som de 15-64-årige, eller

- Vil opretholde en uændret forsørgerkvote, defineret som forholdet mellem de 15-64-årige og gruppen af personer på 65 år og derover.
En uændret befolkning vil med de givne antagelser kræve en indvandring til de daværende 15 EU-lande på 47,5 mio. frem mod 2050. En uændret arbejdsstyrke vil kræve en indvandring på 79,4 mio. frem mod 2050, mens en uændret forsørgerkvote vil kræve en indvandring på 674 mio. frem mod 2050

Tallene kommer oven i en forudsat indvandring til EU-15 i FN's grundscenarie på 300.000 om året eller 16,1 millioner frem til 2050.

Beregningerne viste altså, at der er tale om et pyramidespil, hvis manglen på arbejdskraft skal løses ved indvandring. I løbet af få årtier vil der ske en eksplosiv vækst i det samlede folketal - og værtsbefolkningen vil med en antagelse om uændret forsørgerkvote blive en minoritet.

Ved FN-beregningerne er antaget, at en person, der glider ud af arbejdsstyrken på grund af alder, uden videre problemer kan erstattes af en indvandrer, samt at indvandrerne straks overtager værtsbefolkningens lave fertilitet.

Når værtsbefolkningen kan komme i klart mindretal i løbet af ganske få årtier, er forklaringen, at indvandrerne også bliver gamle og skal erstattes af nye indvandrere. Systematisk indvandring af arbejdskraft er en kortsigtet løsning, som øger forsørgerbyrden på længere sigt - med mindre altså, at indvandrerne hentes til Europa for at arbejde i nogle år og derefter returnerer til deres hjemland, som det bl.a. kendes fra Singapore for 'low-skilled workers' og fra de arabiske Golf-lande.

Løsningen på befolkningens aldring er i første række, at værtsbefolkningen ar-

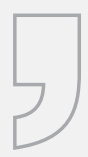

\footnotetext{
Systematisk indvandring af arbejdskraft er en kortsigtet løsning, som øger forsørgerbyrden på længere sigt - med mindre altså, at indvandrerne hentes til Europa for at arbejde i nogle år og derefter returnerer til deres hjemland, som det bl.a. kendes fra Singapore.
} 
bejder - og betaler skat - i flere år end de nærmest foregående generationer. I mange lande i Europa er pensionsalderen stadig temmelig lav - og tiden på pension er mærkbart længere end for tidligere generationer på grund af længere middellevetid. Dog har man i en række lande under store protester fra faglige organisationer fået hævet pensionsalderen en smule i de senere år. I nogle europæiske lande er kvindernes erhvervsfrekvens desuden noget lavere end i bl.a. de skandinaviske lande, så her er der også arbejdskraftreserver at trække på.

\section{Konklusion}

Migration er blevet kaldt globaliseringens menneskelige ansigt, men den er ikke en selvfølgelig konsekvens af globalisering. Tværtimod bygger væksten i international handel og specialisering på, at der er forskel på produktionsomkostningerne i forskellige lande, og at folk i lavindkomstlande ikke kickstarter vejen til velstand ved at flytte til et højindkomstland.

Få problemer i Europa er i dag så kontroversielle som irregulær migration, der af et flertal af vælgerne opfattes som ukontrolleret, når tallet bliver stort, og antallet af synlige minoriteter akkumulerer, jævnfør en vækst i eksempelvis Danmark fra godt 50.000 til knap 500.000 på 35 år. Det skyldes til dels, at migrationen berø- rer så mange andre spørgsmål, økonomi, demografi, politik, national identitet, kultur og endog religion.

Vi befinder os i et dilemma. Vi vil undgå ulemperne og truslerne ved ukontrolleret indvandring af flygtninge og økonomiske migranter, og vi har hidtil - af humanitære grunde - villet undgå midlerne til at dæmme op for ukontrolleret indvandring med effektiv grænsekontrol og hjemsendelse, idet vi fortsat klynger os til et selvbedrag om at kunne integrere alle indvandrere, som kommer.

Men som nævnt i Taksøe-Jensen-rapporten er der udsigt til en voldsom og uafvendelig befolkningsvækst i Mellemøsten og Afrika allerede i de kommende 15 år. Det er fattige lande med et højt konfliktniveau og med potentielle flygtninge som konsekvens. Forskellige undersøgelser viser, at en meget stor andel unge i disse lande drømmer om at komme til Europa. At komme gennem 'Himlens dør' med et udtryk af den amerikansk-cubanske immigrationsøkonom George Borjas.

Derfor er migration en sikkerhedspolitisk udfordring for Danmark og EU, hvilket såvel Taksøe-Jensen-rapporten som regeringens udenrigs- og sikkerhedspolitiske strategi klogt retter blikket mod. 